\title{
Extraction, characterization and quantification of resveratrol from the inemaking pomace: emphasis on the vacuum drying process
}

\author{
Extração, caracterização e quantificação do resveratrol a partir do bagaço \\ da vinicultura: ênfase no processo de liofilização a vácuo \\ Silvia Cândida Correa Fernandes Botti ${ }^{1}$, Antônio Odair Santos ${ }^{3}$, Inaldo Dias ${ }^{1}$, Francisco Tadeu Degasperi ${ }^{1,2}$, Silvia Pierre Irazusta ${ }^{1,4}$
}

\section{ABSTRACT}

The main residue of the winemaking process is the grape pomace, which is rich in bioactive compounds such as resveratrol, known by its therapeutic and cosmetic value as well as its natural antioxidant characteristics. The present work aimed to study methods of preservation and extraction of resveratrol envisaging a sustainable use of winemaking disposal residues. This work carried out a comparative analysis of bagasse drying methods, using thermal process dewatering and freeze drying or lyophilization, using a vacuum process, both prior to the extraction process of resveratrol. The analytical characterization of the extract, by Fourier Transform Infrared (FTIR) and High Performance/Pressure Liquid Chromatography (HPLC) allowed, respectively, the identification and quantification of resveratrol, indicating the freeze-drying of pomace as the best way of preserving its content in the sample.

Keywords: Grape pomace, Resveratrol, Lyophilization.

\section{RESUMO}

O principal resíduo do processo de vinificação é o bagaço de uva, que é rico em compostos bioativos como o resveratrol, conhecido pelo seu valor terapêutico e cosmético, bem como por sua característica antioxidante. Este trabalho realizou uma análise comparativa dos métodos de secagem de bagaço usando a desidratação por processo térmico e a liofilização, utilizando processo a vácuo, ambos previamente ao processo de extração do resveratrol. A caracterização analítica do extrato, pela Espectroscopia de Infravermelho por Transformada de Fourier (FTIR) e Cromatografia Líquida de Alto Desempenho (HPLC) permitiram, respectivamente, a identificação e quantificação do resveratrol, indicando a liofilização do bagaço como a melhor maneira de preservar seu conteúdo na amostra.

Palavra-chave: Bagaço, Resveratrol, Liofilização.

${ }^{1}$ Centro Estadual de Educação Tecnológica Paula Souza - ETEC Benedito Storani - Jundiaí/SP - Brazil.

${ }^{2}$ Faculdade de Tecnologia do Estado de São Paulo - São Paulo/SP - Brazil.

${ }^{3}$ Instituto Agronômico de Campinas - Jundiaí/SP - Brazil.

${ }^{4}$ Faculdade de Tecnologia do Estado de São Paulo - Programa de Mestrado Profissional em Gestão e Tecnologia em Sistemas Produtivos - Sorocaba/SP - Brazil. Correspondence author: Silvia Cândida Correa Fernandes Botti | Centro de Estadual de Educação Tecnológica Paula Souza - ETEC Benedito Storani | Av. Antônio Frederico Ozanan, 9200 | CEP 13.214-206 - Jundiaí/SP - Brazil | E-mail: silviacfernandes@terra.com.br

Received: March 15, 2018 | Approved: June 26, 2018 


\section{INTRODUCTION}

The agricultural sector produces a great quantity of byproducts and residues and, nowadays, the related recycling represents a raising industry, both for economic, environmental and sustainability reasons. This is also true when those are wastes from winemaking process ${ }^{1}$. Wineries are among the industries that suffer most from the accumulation of organic waste, in addition to those seeking new technologies to add value to the environment, and reduce environmental impact. Although the wineries generate biodegradable waste, they need a minimum degradation time, constituting a source of pollutants ${ }^{2}$.

According to industry reports, during the production of $100 \mathrm{~L}$ of red wine, was also obtained $25 \mathrm{~kg}$ of by-products and $17 \mathrm{~kg}$ are grape pomace, i.e. $68 \%{ }^{3}$. Thus, grape pomace is the main residue generated in the winemaking process, and its reuse has an important impact on reducing waste. Furthermore, its recycling is worth since this material has several bioactive substances rich in polyphenols ${ }^{4}$.

Among the phenolic compounds, the anthocyanins, flavonoids and stilbene derivatives present peculiar characteristics and play important roles in plants, such as responses to stressful situations derived from pathogens attack ${ }^{5,6}$. Within the class of stilbenes, the resveratrol has particular importance by its assigned biological properties as antioxidant, anti-inflammatory, anti-neoplasia, and its cardiovascular protective traits ${ }^{6-12}$.

Resveratrol (Fig. 1) works as a phytoalexin synthesized in plants both in response to biotic stress, such as grape injuries due to fungal action, and by abiotic stress, such as exposure to ultraviolet radiation ${ }^{13}$.<smiles>Oc1ccc(/C=C/c2cc(O)cc(O)c2)cc1</smiles>

Figure 1: Chemical structure of trans-resveratrol ${ }^{14}$.

The removal of water from the bagasse can be carried out by thermal dehydration process or by lyophilization process.

The dehydration can occur in a natural or an artificial way. In this work artificial way was used, that is to say, by means of dehydrators with injection of heat and controlled air velocity ${ }^{15}$. In this type of drying the heat is produced by artificial energy source (electric stove, heater by fossil fuel, and others), with controlled temperature and air current, in this case, the temperature of $50{ }^{\circ} \mathrm{C}$ to $70^{\circ} \mathrm{C}$. The mass of moving air conducts heat to the food, causing the evaporation of the water, being the transport vehicle of the wet vapor released by the food ${ }^{16}$. The major disadvantage of this drying process is that in addition to water, other products can also evaporate, thereby altering the physical properties (shape, consistency, hardness, and other important properties of the material), as well as organoleptic properties.

On the other hand, lyophilization or freeze-drying is a widely used physical process for the preservation of various products, e.g. food, medicines, vaccines, stuffed animals, and others ${ }^{17}$, and its applications increased in recent years. In the case of food, this process allows its long-term storage maintaining the organoleptic and physicochemical characteristics of the product. The lyophilization process combines the freezing of the product from which water will be removed, and then the pressure decrease. Thus, in lyophilization, the removal of water occurs with the material at low temperature. Physically speaking, the removal of water in the freeze-drying occurs through sublimation, which is passing from the water in the solid state to the gaseous state, without passing through the liquid state (Fig. 2).

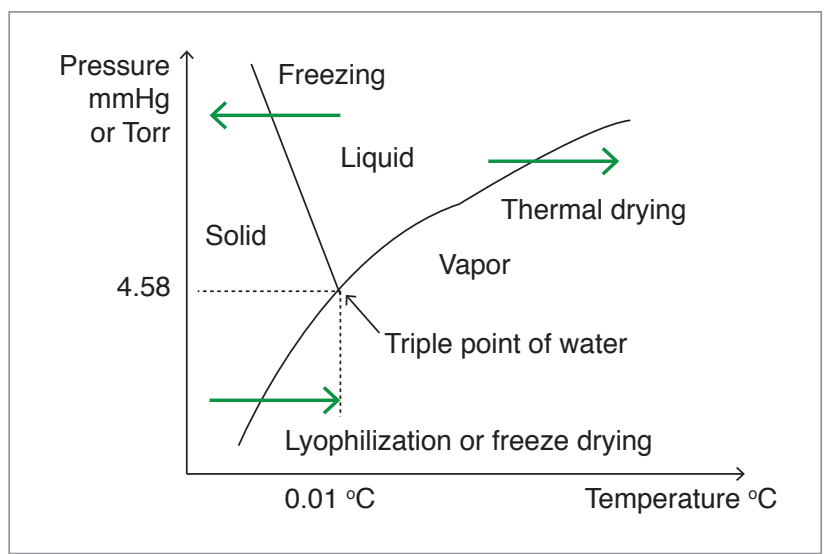

Figure 2: Water phase diagram ${ }^{18}$.

The pomace of two grape varieties, Carmenere and Cabernet Sauvignon, were studied and the freeze-drying kept all volatile and phenolic compounds in comparison with the original values ${ }^{19}$.

This work investigated two sample preparation methods (conventional drying and lyophilization), in order to comparatively evaluate preservation of resveratrol quality, as well as its content in the residue of the winemaking process, envisaging maximizing its potential use as a by-product. Nonetheless, the investigation seeks to provide an auxiliary tool to support decision-making as to the grape harvest, based upon the stratification of resveratrol concentrations, prior to it, which would allow, for example, the production of functional foods and beverages, through withinfield differential harvesting ${ }^{20}$. These possibilities justify the search for improvements in methods of extraction and purification of resveratrol as a by-product of winemaking process.

\section{MATERIAL AND METHODS}

\section{Obtaining the Sample}

Eighty $\mathrm{kg}$ of grape Syrah (Vitis vinifera L.) were collected in a vineyard located in Jundiaí (São Paulo State, Brazil). After 
primary fermentation and skin separation, a total of $55 \mathrm{~L}$ of wine were accounted, being $15 \mathrm{~kg}$ of pressed pomace, say $18.8 \%$ of the initial grape mass.

The grape pomace was divided into portions, which were stored in the fridge for four days, at a temperature of $10^{\circ} \mathrm{C}$. Afterwards part of these samples was dehydrated (oven-dried) and part was freeze-dried.

\section{Dehydration (oven-drying)}

Part of grape pomace, corresponding to $3 \mathrm{~kg}$, was submitted to dehydration in an oven (Pardal dehydrator) at $50^{\circ} \mathrm{C}$ for $5 \mathrm{~h}$. After this process the samples were frozen at $-18{ }^{\circ} \mathrm{C}$ until analysis.

\section{Lyophilization}

The frozen residue was inserted in the lyophilizer, initiating the process of drying. Lyophilization occurred, on average, for $15 \mathrm{~h}$ with pressure of $(4.1 \pm 0.2) \times 10^{-1} \mathrm{mbar}$, and drying chamber temperature of $-20{ }^{\circ} \mathrm{C}$. After this process, the samples that were at about $0{ }^{\circ} \mathrm{C}$ were immediately frozen at $-18{ }^{\circ} \mathrm{C}$ until analysis took place. Thus, the sequence for lyophilization of the sample is as follows: the cooling, before being placed in the vacuum system to carry out the lyophilization process, was done in a freezer at a temperature of $-18{ }^{\circ} \mathrm{C}$; after freeze-drying, the lyophilized sample was conditioned in a plastic bag (clean, of the type used to store food) and returned to the household freezer; then it was sent to the analysis in styrofoam boxes with ice. The temperature measurement was performed with type $\mathrm{K}$ thermocouple.

Figure 3 shows the lyophilizer scheme. It basically consists of a vacuum chamber, a filter, a vacuum pump and an exhaust filter.

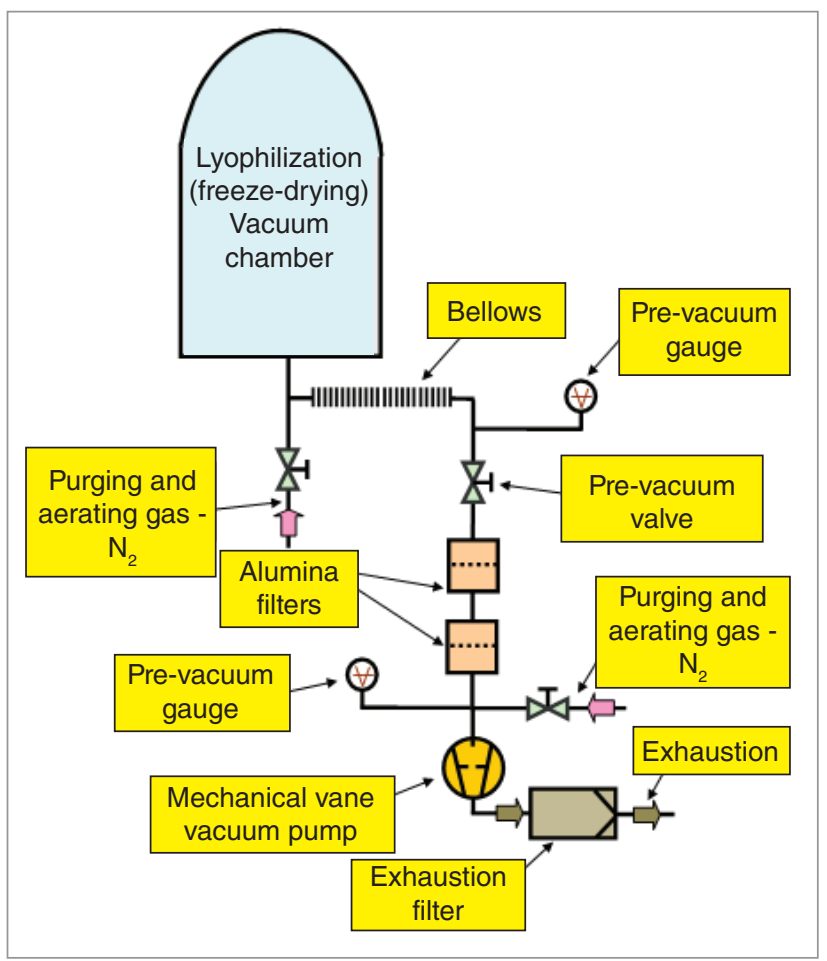

Figure 3: Vacuum system for freeze-drying of food.
The pre-vacuum (rough-vacuum and medium-vacuum) system is based on a vacuum chamber with conventional elastane (nitrile rubber) seals and a dual-stage mechanical type pre-vacuum pump. Due to the fact that the mechanical vane pump is not efficient for pumping vapors (in the case of lyophilization performed here, the water vapor must be removed), the vacuum pump must be protected by the installation of filters capable of retain water vapor. To make water vapor retention more efficient, two alumina filters were installed along the pumping line. There is also the placement of a metal bellows to mechanically couple the parts of the vacuum system (vacuum chamber and pumping line) and a pre-vacuum valve to isolate the pumping line from the vacuum chamber, for the exchange of samples to be lyophilized. The vacuum gauges used are of the Pirani type. An exhaust filter is required so that the experiment room is not contaminated with oil vapor from the mechanical vane pump (this vacuum pump is lubricated with mineral oil). At the end of the lyophilization process, the aeration of the vacuum chamber is done with nitrogen gas $\left(\mathrm{N}_{2}\right)$.

\section{Determination of Moisture}

Final moisture was determined by using infrared moisture Analyzer equipment (IV 2500 Gehaka).

\section{Extraction of Polyphenols}

The extracts of the waste were obtained as described by Liu et al. ${ }^{21}$, employing methanol and ethyl acetate as solvents. Initially, $1 \mathrm{~g}$ of dehydrated pomace and $1 \mathrm{~g}$ of lyophilized pomace were taken in tubes, followed by addition of $5 \mathrm{~mL}$ of solvent methanol solution and $5 \mathrm{~mL}$ of ethyl acetate. The samples were kept in the dark for $24 \mathrm{~h}$ at room temperature, because modifications in the samples promoted loss, interfering with the amount of resveratrol.

After this period samples were centrifuged at $1000 \mathrm{rpm}$ for $15 \mathrm{~min}$. The supernatant was evaporated to dryness in distiller at $50{ }^{\circ} \mathrm{C}$. The dried resveratrol was suspended in $2 \mathrm{~mL}$ of methanol (in a microtube) and immediately frozen at $-18^{\circ} \mathrm{C}$ until the time of analysis.

\section{Quantitative Analysis by High Performance Liquid Chromatographic (HPLC)}

Resveratrol extracts were analyzed in a gas chromatograph (Shimadzu HPLC SPD 10A), equipped with UV-VIS detector and C18 column of $250 \mathrm{~mm}$ in length, $4 \mu \mathrm{m}$ particle diameter and $60 \mathrm{~mm}$ internal diameter, using the method of Seferin et al. ${ }^{22}$ The volume of resveratrol standard used in this analysis was $20 \mu \mathrm{L}$, which was injected, and then the dehydrated and lyophilized samples were detected at $306 \mathrm{~nm}$. HPLC analysis was conducted in flow isocratic elution of $0.5 \mathrm{~mL} / \mathrm{min}$, run time of $30 \mathrm{~min}$ and pressure of $68 \mathrm{bar}$, using $25 \%$ acetronitrile at $\mathrm{pH} 3.0$ adjusted with $\mathrm{H}_{2} \mathrm{SO}_{4}$.

\section{Qualitative Analysis by FTIR Spectroscopy}

The qualitative analysis of the resveratrol in the samples was also performed by Fourier transform infrared spectroscopy (FTIR). 
The FTIR analysis was first performed to verify the efficiency of the extraction, since it is a technique commercially more viable. This comprised submitting to analysis the sample standard (resveratrol powder diluted in methanol, just the powder without dilution) and later on, the lyophilized and dehydrated samples.

The peaks corresponding to the chemical groupings of the resveratrol molecule in the sample were identified, by comparing the peaks with the available pattern. The resulted peaks represent the "fingerprint" of resveratrol.

\section{Statiscal Analysis}

The average comparison was performed by Student t-test, with $95 \%$ confidence interval.

\section{RESULTS AND DISCUSSION}

The process of dehydration of grape pomace followed two different ways. By means of a traditional dehydrator or by using lyophilization equipment; both processes aimed to preserve the samples characteristics.

The residual moisture levels were, on average, $(12.0 \%( \pm 0.3$, $\mathrm{n}=3)$ for conventional dehydrator and $(8.1 \%( \pm 1.0, \mathrm{n}=4)$ for lyophilization process.

The totals of phenolic compounds per gram of pulp in the extract were $40.0 \mathrm{~g}( \pm 0.6 \mathrm{~g}, \mathrm{n}=3)$ and $40.0 \mathrm{~g}( \pm 1.9 \mathrm{~g}, \mathrm{n}=4)$, respectively, for traditional drying and freeze-drying process (Table 1). Table 2 indicates the yield of crude compound.
Table 1: Comparison of drying yield and moisture content among pomace conservation methods.

\begin{tabular}{|c|c|c|c|c|}
\hline Sample & Dehydrated & Moisture & $\begin{array}{c}\text { Freeze-dried } \\
(\%)\end{array}$ & $\begin{array}{c}\text { Moisture } \\
(\%)\end{array}$ \\
\hline$\mu \pm S D$ & $40.6 \pm 0.6$ & $12.0 \pm 0.3$ & $40.6 \pm 1.9$ & $8.1 \pm 1.0$ \\
\hline
\end{tabular}

Results expressed in $\mathrm{g} / 100 \mathrm{~g}$ of extract. The samples did not present significant difference $(p<0.05) ; \mu \pm$ SD means average \pm Standard Deviation.

Table 2: Comparison of extractions of crude compound.

\begin{tabular}{c|c|c}
\multirow{2}{*}{ Extractions } & \multicolumn{2}{|c}{ Yield of extractions of compound $(\mathbf{g} / \mathbf{1} \mathbf{~ g})$} \\
\cline { 2 - 3 } & Dehydrated & Freeze-dried \\
\hline$\mu \pm S D$ & $0.8 \pm 0.1$ & $0.8 \pm 0.1$ \\
\hline
\end{tabular}

The samples did not present significant difference $(p<0.05)$.

Statistical analysis showed no significant differences between the samples as to moisture content or even about phenolic compounds for both drying processes employed. The nature of the constituents of phenolic compounds was not determined, since this analysis wasn't subject of this study. When the quantification of the resveratrol content of the compounds was the case, this quantification in phenolic extract was performed by HPLC.

The chromatogram showed a "retention time" of $27 \mathrm{~min}$ for the pattern of resveratrol (Fig. 4A). The same retention time was obtained from oven-dried and lyophilized samples (Figs. 4B and $4 \mathrm{C})$. The other peaks on spectra $4 \mathrm{~B}$ and $4 \mathrm{C}$ probably correspond to phenolic compounds simultaneously extracted during sample pretreatment.

(A)

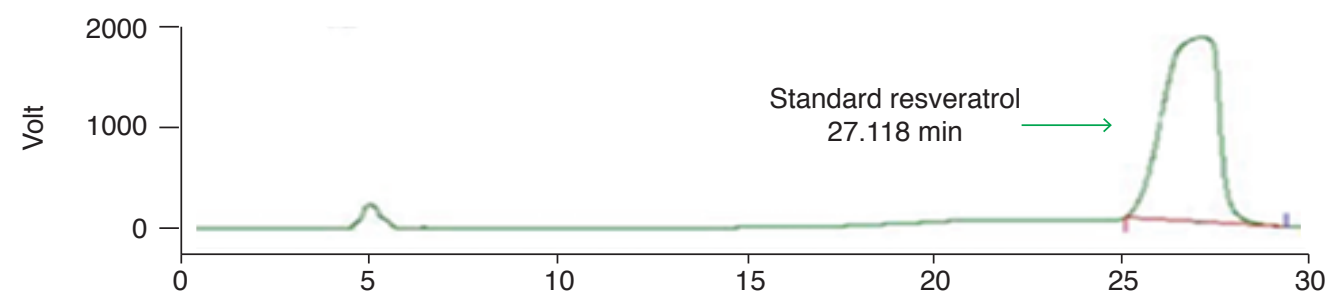

(B)

(C)
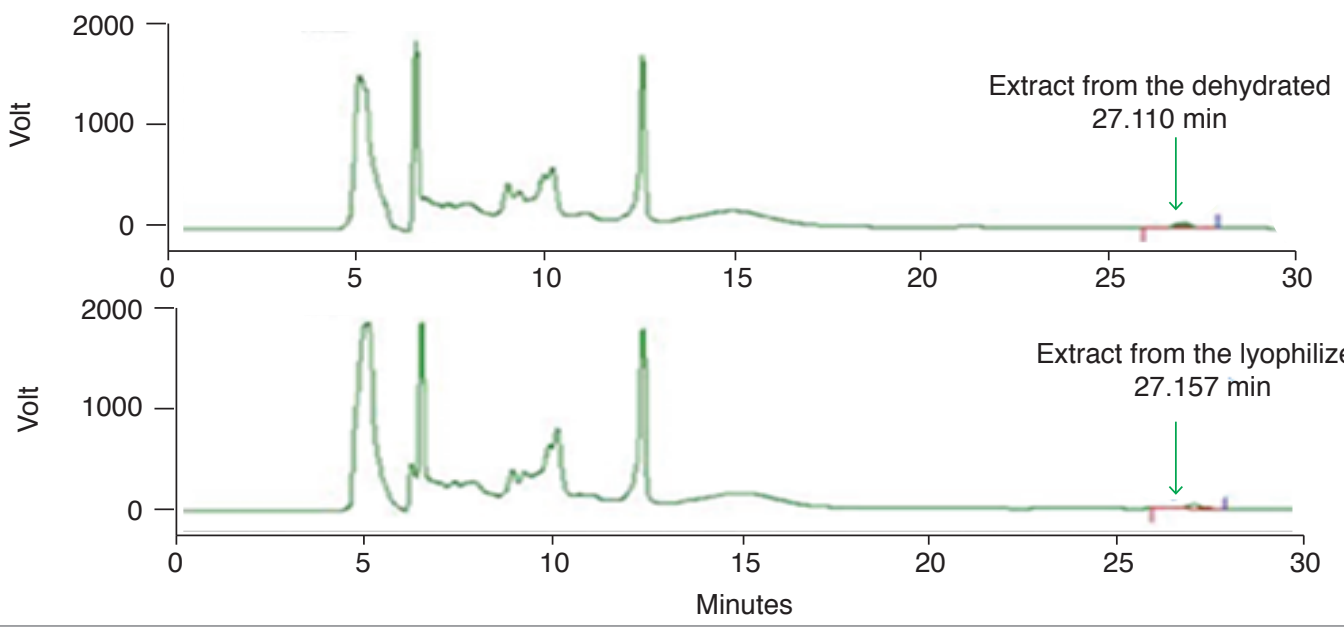

Figure 4: Chromatogram of extract and standard samples. (A) Standard resveratrol; (B) extract from the conventional dehydratation; and (C) extract from the lyophilization. 
The concentration of resveratrol (Table 3 ) was significantly greater in the lyophilized pomace $(0.25 \mu \mathrm{g} / \mathrm{g})$, when compared with the oven-dried grape pomace $(0.04 \mu \mathrm{g} / \mathrm{g})$.

Table 3: Concentration of Resveratrol in $\mu \mathrm{g} / \mathrm{g}$.

\begin{tabular}{c|c|c} 
Sample & $\begin{array}{c}\text { Dehydrated } \\
(\mu \mathrm{g} / \mathrm{g})\end{array}$ & $\begin{array}{c}\text { Freeze-dried } \\
(\mu \mathrm{g} / \mathrm{g})\end{array}$ \\
\hline$\mu \pm \mathrm{SD}$ & $0.04 \pm 0.01$ & $0.25 \pm 0.09^{*}$ \\
\hline
\end{tabular}

Results expressed in $\mu g / g$. The samples present significant difference $*(p<0.05)$.

Table 4 presents the consolidated data of the results of the comparative analysis between the drying processes. The significant difference between methods highlights the performance of the active ingredient, resveratrol, with advantage for freeze-drying methodology.

The used FTIR analysis was helpful in the assessment of the presence of resveratrol in the samples. Figure 5 depicts the obtained spectra in the analysis, on the interval between 3500 and $1600 \mathrm{~cm}^{-1}$ that corresponds to the four most intense bands collected, as follows: the diluted standard sample (Fig. 5A), lyophilized residue (Fig. 5B), and the dehydrated residue (Fig. 5C). Figure 5D shows the spectra for the grouped samples. There is the presence of characteristic absorption bands between.

The data are in accordance with related results obtained by Mendes et al. $^{23}$, to whom a characteristic absorption broad band for pure resveratrol was expected around $3257 \mathrm{~cm}^{-1}$, and other on $1610 \mathrm{~cm}^{-1}$, corresponding to $\mathrm{C}-\mathrm{C}$ aromatic doublebond stretching. These bands can be clearly seen on the spectra, although the $3257 \mathrm{~cm}^{-1}$ seems to be broader than Mendes et al. ${ }^{23}$ results, probably due to water and/or methanol presence. The $\sim 2900$ and $\sim 2800 \mathrm{~cm}^{-1}$ bands can be assigned to $\mathrm{C}-\mathrm{H}$ and $\mathrm{CH}_{2}$ asymmetric and symmetric stretching and, again, can indicate methanol presence but also phenolic coumpounds ${ }^{24}$. In any case, these results indicate that FTIR might be a useful tool for qualitative assignment of the presence of resveratrol on the samples.

Table 4: Consolidated data on the quantitative parameters of extracts.

\begin{tabular}{|c|c|c|}
\hline Variables & $\begin{array}{c}\text { Conventional } \\
\text { dehydration }\end{array}$ & Freeze-dried \\
\hline $\begin{array}{c}\text { Resveratrol concentration }(\mu \mathrm{g} / \mathrm{g}) \\
\mu \pm S D\end{array}$ & $0.04 \pm 0.01$ & $0.25 \pm 0.09$ \\
\hline $\begin{array}{c}\text { Moisture } \% \\
\mu \pm S D\end{array}$ & $12 \pm 0.3$ & $8.1 \pm 1.0$ \\
\hline
\end{tabular}

The reduction of free water from food raises the osmotic pressure of their environment and, consequently, decreases the potential for microorganisms proliferation on it and the enzymes that are able to impart modifications trough oxidation process lose their activity ${ }^{15}$. Therefore, water removal influences two important basic parameters, which are vital for the conservation of chemical and microbiological traits of grape pomace.
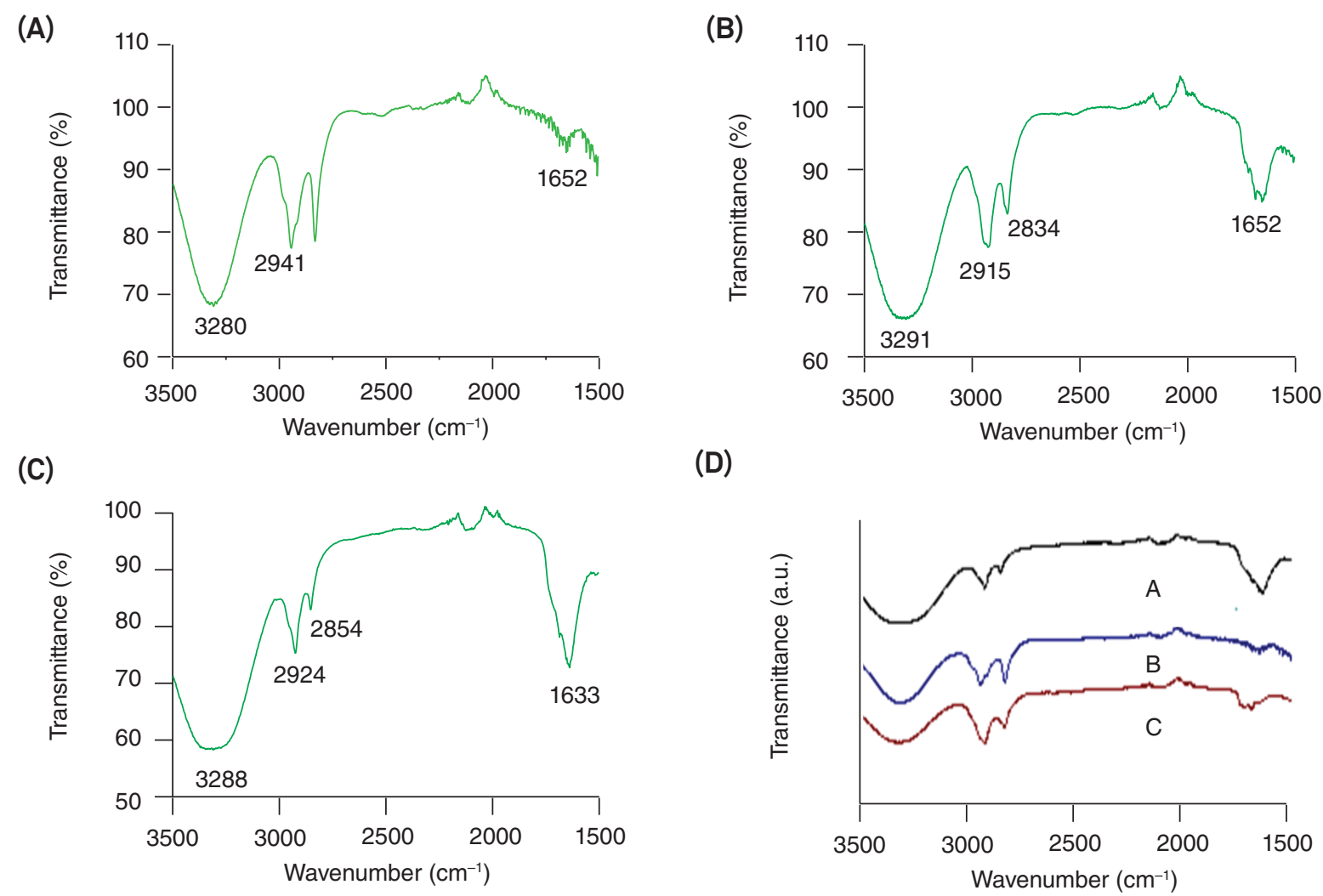

(D)

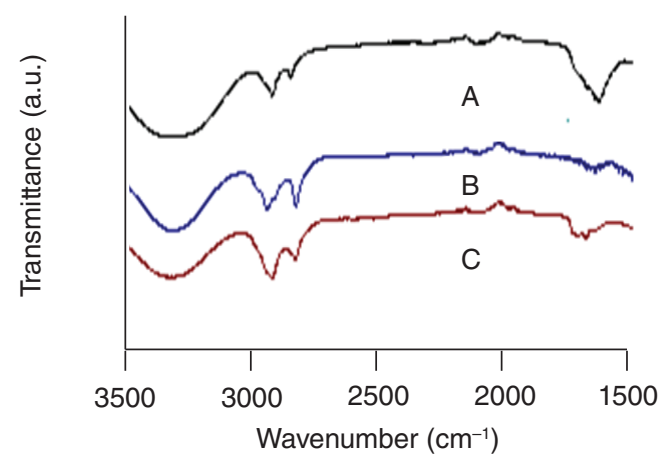

Figure 5: FTIR Spectra in (A) dilute resveratrol standard; (B) lyophilized bagasse, (C) dehydrated bagasse; and (D) grouping of samples. 
In this study, the results showed that there was no significant difference between the values of moisture and final amount of the phenolic compounds resulting from the two processes of conservation. It was noted, however, that the content of the active ingredient (resveratrol), yielded when liophylization was applied, was significantly higher, as compared to ovendried process $(0.25 \mu \mathrm{g} / \mathrm{g} \pm 0.09 \mu \mathrm{g} / \mathrm{g}$ for lyophilization, $0.04 \mu \mathrm{g} / \mathrm{g} \pm 0.01 \mu \mathrm{g} / \mathrm{g}$, for oven-dried) (Table 4).

This result is (probably) not exudation of bioactive material during the production and transportation of steam in the process of lyophilization, at low operating temperatures, keeping the resveratrol in the structural matrix ${ }^{15}$.

The lyophilization process proved to be more efficient also in conservation of the compounds, color preservation of the pomace and the general appearance of the product. In spite of these characteristics not being related directly to the target study, since anthocyanins are responsible for the color, they indicate that the lyophilization process has advantages in preserving color and texture. Although it is a subjective evaluation, this observation represents a relevant aspect in the quality of the final product (Fig. 6).

Usually the drying process occurs at atmospheric pressure, where the exchange of heat is done by a forced convective way. The mass of moving air conducts heat, causing evaporation of the water, say the damp vapor released by food ${ }^{16}$. The major drawback of this drying process is that besides the water, other products can also evaporate, thus changing the physical properties (shape, firmness and hardness).

The lyophilization process combines the freezing of the product to be dehydrated, followed by decrease of pressure. In this way, the water removal by lyophilization takes place with the material at low temperature through the phenomenon of sublimation, which is the transition of water from the solid state to the gaseous phase, without going through the liquid phase ${ }^{17}$. It is seen that the applications of that process has been increased in recent years. In the case of foods it allows the storage for a long period, keeping the nutritional and physicalchemical properties of the product ${ }^{25}$.

In liophylization the product is frozen, followed by the application of vacuum to the occurrence of the sublimation and consequently the dehydration, with the loss of water ${ }^{18}$. The result is the reduction of the volume of the product, with the preservation of its color, flavor, aroma and nutritional characteristics, which remain almost intact after rehydration. The water content is evaporated directly, without breaking molecular membrane structures, keeping intact the nutrients, consistency and taste of the food ${ }^{15}$. Thus, the process is optimized for low temperature and in the absence of atmospheric air ${ }^{16}$

The lyophilization protects against the degradation of phenolic compounds, in contrast to the conventional process, since the drying up of $60^{\circ} \mathrm{C}$ decreases significantly the activity of polyphenols, as seen for Mulberry (Morus alba L.). Therefore, lyophilization process can be an option for the food industries to improve the color and aroma of grapes low in anthocyanins ${ }^{19}$.

Considering the content of the active ingredient, Careri et al. ${ }^{26}$ found $6.0 \mu \mathrm{g} / \mathrm{g}$ of resveratrol for residual grape pomace for the variety Nero d'Avola, while Sato et al..$^{27}$ found $7.6 \mu \mathrm{g} / \mathrm{g}$, for grape Alicante and $6.4 \mu \mathrm{g} / \mathrm{g}$ for grape Syrah. The different environmental conditions, species and cultural practices and winemaking techniques used ${ }^{6,12}$ could explain the differences between obtained results. Particularly, for the above-mentioned data for Syrah, the authors used a different extract from the berries of the grape, obtainable with another solvent, different from that used in this work.

In general the results showed a great potential for resveratrol extraction on a large scale, using lyophilization method and reinforced this methodology as a viable alternative for optimization of sample preservation. This is true both for grape pomace and for in natura fruit.

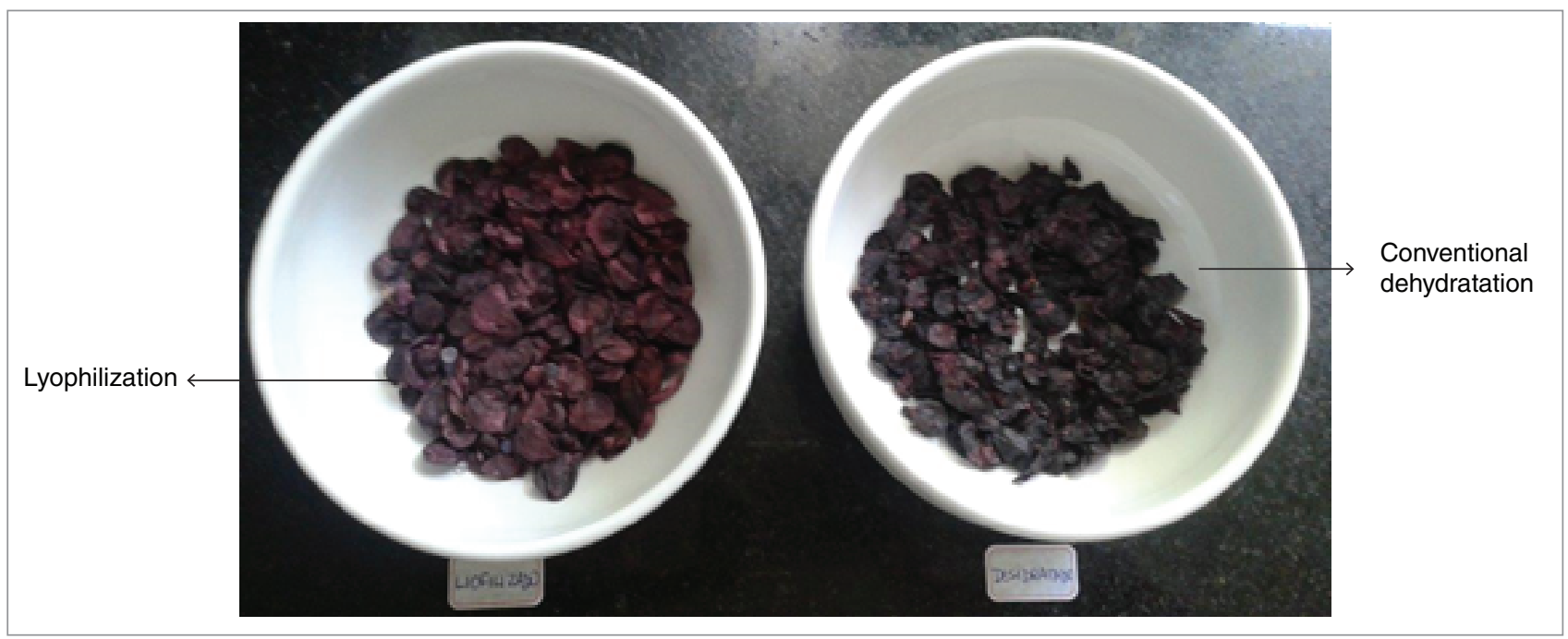

Figure 6: Visual characteristics of pomace dried by conventional and lyiphilization method 


\section{CONCLUSIONS}

Taken together, our results demonstrate that the pomace waste proved to have resveratrol in the structural matrix, which was better preserved by the lyophilization method compared to conventional dehydration. The quantitative (HPLC) and qualitative (FTIR) analysis confirmed the established in this work. FTIR analysis is a faster and more commercially friendly method, while HPLC provides the more accurate measurements.

When it comes to processing time, while conventional dehydration required $4 \mathrm{~h}$ for drying, lyophilization required $24 \mathrm{~h}$ in the experimental conditions used. In this way, for being a more time-consuming technique, lyophilization can mean a negative impact when considering only the largest energy expenditure. However, in terms of yield of active ingredient, that method showed to be significantly more effective.

The study points out the potential of resveratrol modeling into calibrated FTIR instrumentation. This can allow for the production of functional foods and beverages by setting up of vineyard selective harvesting.

\section{ACKNOWLEDGEMENTS}

We thank the laboratory technicians from School of Chemistry Conselheiro Antonio Prado and the National School for Industrial Learning (SENAI), who kindly granted the equipment and the Pharmaceutics, compounding pharmacy, and also for the donation of the resveratrol compound.

\section{REFERENCES}

1. Spigno G, Pizzorno T, De Faveri DM. Cellulose and hemicelluloses recovery from grape stalks. Bioresource Technology. 2008;99(10):4329-4337. Available from: https:// doi.org/10.1016/j.biortech.2007.08.044

2. Huber K, Queiroz JH, Moreira AVB, Ribeiro SMR. Caracterização química do resíduo agroindustrial da manga ubá (Mangifera indica L.): uma perspectiva para a obtenção de antioxidantes naturais. Revista Brasileira de Tecnologia Agroindustrial. 2012;6(1):640-654. Available from: http://doi. org/10.3895/S1981-36862012000100003

3. Campos AT. Compostagem [internet]. Brasília: Agência de Informação Embrapa. Agronegócio do Leite. [Cited 2014 May 3]. Available from: http://www.agencia.cnptia.embrapa. br/Agencia8/AG01/arvore/AG01_255_217200392410.html

4. Sales NFF, Cruz APG, Cabral LMC, Torres AG. Capacidade antioxidante de extratos hidroalcoólicos do bagaço de uva tinta. XIX Congresso Brasileiro de Engenharia Química; Búzios, Brasil; 2012.

5. Vaccari NSF, Soccol MCH, Ide GM. Phenolic compounds in wine and its antioxidant effects in the prevention of diseases. Journal of Agroveterinay Sciences Magazine. 2009;8(1):71-83.

6. Flamini R, Mattivi F, Rosso M, Arapitsas P, Bavaresco L. Advanced knowledge of three important classes of grape phenolics: stilbenes and flavonols, anthocyanins. International Journal of
Molecular Sciences. 2013:14(10):19651-19669. Available from: http://doi.org/10.3390/ijms141019651

7. Frankel EN, German JB, Kinsellaa JE, Parks E, Kanner J Inhibition of oxidation of human low density lipoprotein by phenolic substances in red wine. The Lancet. 1993;341(8843):454-457. Available from: https://doi. org/10.1016/0140-6736(93)90206-V

8. Wang Z, Huang Y, Zou J, Cao K, Xu Y, Wu JM. Effects of red wine and wine polyphenol resveratrol on platelet aggregation in vivo and in vitro. Int J Mol Med. 2002:9(1):77-79. Available from: https://doi.org/10.3892/ijmm.9.1.77

9. Moraes V, Locatelli C. Wine: a review on the chemical composition and health benefits. Evidência. 2010;10(1-2):57-68.

10. Harborne JB, Williams CA. Advances in flavonoid research since 1992. Phytochemistry. 2000:55(6):481-504. Available from: https://doi.org/10.1016/S0031-9422(00)00235-1

11. Lee C-W, Yen F-L, Huang H-W, Wu T-H, Ko H-H, Tzeng W-S, Lin C-C. Resveratrol Nanoparticle System Improves Dissolution Properties and Enhances the Hepatoprotective Effect of Resveratrol through Antioxidant and Anti-Inflammatory Pathways. J Agric Food Chem. 2012;60(18):4662-4671. Available from: http://doi.org/10.1021/jf2050137

12. NNSS Hashim, Schwartz LJ, Boysen RI, Yang Y, Danylec B, Hearn MTW. Solid-phase extraction and Rapid analysis of resveratrol and other polyphenols in red wine. Journal of Chromatography A. 2013;1313(25):284-290. Available from: https://doi.org/10.1016/j.chroma.2013.06.052

13. Sautter CK, Denardin SO, Alves AO, Mallmann CA, Penna NG, Hecktheuer LH. Determination of resveratrol in grape juice in Brazil. Food Science and Technology. 2005;25(3):437-442. Available from: http://dx.doi.org/10.1590/S0101-20612005000300008

14. Bastos DHM, Rogero MM, Arêas JAG. Mecanismos de ação de compostos bioativos dos alimentos no contexto de processos inflamatórios relacionados à obesidade. Arquivos Brasileiros de Endocrinologia \& Metabologia. 2009;53(5):646-656. Available from: http://doi.org/10.1590/ S0004-27302009000500017

15. Evangelista J. Food technology. 2nd ed. São Paulo: Ed. Atheneu; 2005.

16. Gava AJ, Bento CA, Frias JRG. Food technology: principles and applications. 2nd ed. São Paulo: Nobel; 2009.

17. Ratti C. Hot air and freeze-drying of high-value foods: a review. Journal of Food Engineering. 2001;49(4):311-319. Available from: https://doi.org/10.1016/S0260-8774(00)00228-4

18. Metta IK, Ayrosa AMIB, Paletta FC. O papel da liofilização na conservação de alimentos pelo controle da umidade. XII Safety, Health and Environment World Congress; São Paulo, Brazil; 2012.

19. Torres C, Díaz-Maroto MC, Hermosín-Gutiérrez I, PérezCoello MS. Effect of freeze-drying and oven-drying on volatiles and phenolics composition of grape skin. Analytica Chimica Acta; 2010;606(1-2):177-182. Available from: https:// doi.org/10.1016/j.aca.2009.10.005

20. Santos AO, Moreira CA. Manufacturing vineyard machinery for small business grape growers. International Journal of New Technology and Research. 2015;1:04-08.

21. Liu C, Wang L, Wang J, Wu B, Liu W, Fan P, Liang Z, Li S. Resveratrols in Vitis berry skins and leaves: their extraction and analysis by HPLC. Food chemistry. 2012;136(2):643649. Available from: https://doi.org/10.1016/j.foodchem. 2012.08.017 
22. Seferin M, Souto AA, Carneiro MC, Senna MJH, Conz A, Gobbi K. Determinação de trans-resveratrol em vinhos gaúchos por HPLC. Reunião Anual da Sociedade Brasileira de Química; Poços de Caldas, Brazil; 2000.

23. Mendes JBE, Riekes MK, Oliveira VM, Michel MD, Stulzer HK, Khalil NM, Zawadzki SF, Mainardes RM, Farago PV. PHBV/ PCL microparticles for controlled release of resveratrol: physicochemical characterization, antioxidant potential, and effect on hemolysis of human erythrocytes. The Scientific World Journal. 2012;2012:542937. Available from: http:// dx.doi.org/10.1100/2012/542937

24. Rizwana H, Alwhibi MS, Soliman DA. Antimicrobial activity and chemical composition of flowers of Matricaria aurea a native herb of Saudi Arabia. International Journal of Pharmacology. 2016;12(6):576-586. Available from: http://doi.org/10.3923/ ijp.2016.576.586
25. Marques LG. Liofilization of tropical fruits [PhD Thesis]. São Carlos: Federal University of São Carlos; 2008.

26. Careri M, Corradini C, Elviri L, Nicoletti I, Zagnoni I. Direct HPLC analysis of quercetin and trans-resveratrol in red wine, grape, and winemaking byproducts. J Agric Food Chem. 2003;51(18):5226-5231. Available from: http://doi. org/10.1021/jf034149g

27. Sato AJ, Rosa CALF, Menezes D, Kwiatkowsk A, Clemente E, Roberto SR. Caracterização fenólica de uvas 'Alicante' e 'Syrah' cultivadas em safra fora de época. Revista Brasileira de Fruticultura. 2012;34(1):116-123 